\title{
The Curious Fate of Edward Said in Russia
}

David Schimmelpenninck van der Oye

\section{(2) OpenEdition}

Journals

\section{Electronic version}

URL: http://journals.openedition.org/edl/686

DOI: $10.4000 /$ edl.686

ISSN: 2296-5084

\section{Publisher}

Université de Lausanne

\section{Printed version}

Date of publication: 15 September 2014

Number of pages: 81-94

ISBN: 978-2-940331-35-2

ISSN: 0014-2026

\section{Electronic reference}

David Schimmelpenninck van der Oye, "The Curious Fate of Edward Said in Russia », Études de lettres [Online], 2-3 | 2014, Online since 15 September 2017, connection on 18 December 2020. URL : http:// journals.openedition.org/edl/686; DOI : https://doi.org/10.4000/edl.686 


\section{THE CURIOUS FATE OF EDWARD SAID IN RUSSIA}

This article examines the reception of Edward Said's book Orientalism in Russia. While Said made little mention of Russia, a number of scholars, including Russians abroad like Vera Tolz and Alexander Etkind, have examined Russian Orientalism according to Said's schema. As for Russia itself, the book remains relatively understudied. I explain why Said has been largely ignored in Russia, as well as the appropriation of his ideas by the nationalist right.

The entire history of the relationship between East and West, from the Greeks in antiquity through the time of the Crusades in the Middle Ages, and extending up to the modern and contemporary era... [was marked] by attempts [on the part of the West] to enslave the East...rendering the East voiceless... [Naturally] this sinister enterprise [was] reflected in the scholarship of the East.

S. F. Oldenbourg, «Sovietskoe vostokovedenie», p. 65.

Literature about the colonies has become a weapon of the European elite's political propaganda in their colonialist aggression.

S. Vel'tman, Vostok v khudozhestvennoi literature, p. 42 .

Most would ascribe these statements to the late Columbia University professor of comparative literature, Edward Said. They would also guess that the passages are from his influential book of 1978, Orientalism, which argued that European academics studied Asia all the better to 
subjugate it ${ }^{1}$. In fact, they were written by two Soviet academics. Sergei Oldenbourg, a prominent Buddhologist and the permanent secretary of the Academy of Sciences of the USSR penned the first in an article in 1931. Meanwhile, the second quote was from Solomon Weltman's short monograph, in The East in Literature, which was published in 1928. The resemblance of these two Stalin-era texts to the American-Palestinian literary critic is no coincidence. And they suggest why Said's ideas have yet to make their mark in Russia.

Since its publication over thirty years ago, Orientalism has become one of the most influential works in the Humanities ${ }^{2}$. With a homoerotic painting of a young boy wielding an enormous phallic snake on its cover, the paperback enjoys cult status on university campuses throughout North America. There are well over six hundred dissertations that in some way explicitly invoke Said's ideas about Orientalism. They range from such predictable works as Orientalism and the Constructions of Empire in British Romanticism and Orientalism, Islam and the Other in Seventeenth and Eighteenth-Century French Theatre, to edgier contributions to scholarship, like Othering around Technology: TechnoOrientalism, Techno-Nationalism, and Identity Formation of Japanese College Students in the United States, and Orientalism in United States Cyberpunk Cinema from "Blade Runner" to "The Matrix"3.

One might conclude that the thought of Edward Said has replaced that of Karl Marx in the universality of its relevance to the North American academy. However, the case is somewhat different in Russia. Said himself did not have much to say about the matter. His book was mostly about 19th and 20th-century Britain and France, and he virtually ignored other European nations with a strong orientological tradition, such as Germany, the Netherlands and Russia.

The Russian case is a particularly intriguing exception to Said's Orientalist schema, for its colonial conquests were almost entirely

I. E. Said, Orientalism.

2. But not without criticism from a number of Arabists, including B. Lewis, "The Question of Orientalism" and R. Irwin, For Lust of Knowing, nor, for that matter, some prominent cultural theorists on the left. See A. Ahmad, In Theory, p. 159-219.

3. Cf. S. B. Taylor, Ruining Oppositions; D. W. Hammerbeck, Orientalism, Islam and the Other in Seventeenth and Eighteenth-Century French Theatre; S. Kogure, Othering around Technology; C. H. Park, Orientalism in United States Cyberpunk Cinema from "Blade Runner" to "The Matrix". 
contiguous to its borders. If seas separated maritime imperial powers like England, Spain, France and the Netherlands from "their" Orient, tsarist Russia was a continental empire that ruled over Asian nationalities on its frontier. At the same time, Russia spans both Europe and Asia. Saidian notions of "Self" and "Other" were consequently much more vague 4 . Adding to the confusion is the fact that many Russians had Asian roots themselves - and were quite conscious of the fact. Meanwhile, in the 19th century Russians developed one of the most extensive - if not the most extensive - academic institutions for scholarship of the East at such institutions as the Orientological Faculties of Kazan and Saint Petersburg Universities ${ }^{5}$. If the autocracy also established a wideranging apparatus for the study of the East that was more directly subordinated to its colonial ambitions, such as the Asian Section (Aziatskaia chast') of the general staff or the Foreign Ministry's Asian Department (Aziatskii department), Orientologists in universities tended to be more objective and even sympathetic of the nations they studied ${ }^{6}$.

It took some time in the West for scholars to see the relevance of Edward Said to the Russian case. This was not necessarily because Slavists are particularly obtuse. But many Occidentals still see Russia itself as Oriental. In France, for example, one of the leading institutions for teaching its language is the Institut national des langues et civilisations orientales (INALCO) in Paris. And Ezequiel Adamosvky's recent monograph about the image of Russia in France bears the title EuroOrientalism ${ }^{7}$. Attitudes have not much changed from those expressed by a 16th-century English traveller, George Turbeville:

4. To be fair, in his vigorous critique of Said's book, Orientalism: History, Theory and the Arts, J. M. MacKenzie argues that Said's Manichean "self" vs "other" dichotomy does not necessarily apply to the overseas empires either (p. 208 sq.).

5. Although Kazan's Oriental Faculty was closed, and much of its faculty moved to the imperial capital, by Nicholas I in 1854 . The classic overview of the development of Orientology in Imperial Russia remains V. V. Barthold, "Istoriia izucheniia Vostoka v Evrope i Rossii”. See also G. F. Kim, P. M. Shastitko, Istoriia otechestvennogo vostokovedeniia do serediny XIX veka; A. A. Vigasin et al., Istoriia otechestvennogo vostokovedeniia s serediny XIX veka do 1917 goda; D. Schimmelpenninck van der Oye, Russian Orientalism.

6. This point was famously debated on the pages of the Slavic Review and Kritika. See N. Knight, "Grigor'ev in Orenburg, 1851-1862”; A. Khalid, "Russian History and the Debate over Orientalism".

7. E. Adamovsky, Euro-Orientalism. 
The manners are so Turkish like, the men so full of guile, The women wanton, temples stuft with idols that defile The seats that sacred ought to be. The customs are so quaint, As if I were to describe the whole, I fear my pen would faint ${ }^{8}$.

There is another reason why it took so long for Said to make any impact on Russian studies. Until the collapse of the Soviet Union, most denied that it was colonialist in the Western sense. Even in the West, it was often heresy to characterise the USSR as an empire. Because of the vagaries of academic fashion, in the 1970's and 1980's, very few were even interested in the imperial nature of pre-Revolutionary Russia. Postcolonialism simply had no place in Russian and Soviet studies. According to Alexander Etkind:

Just a few decades ago, the idea that Ukraine or even Central Asia were colonies of the Soviet Empire evoked furious resistance on both sides of the Iron Curtain. In the 1990's, post-colonial experts still debated the reasons for not applying their concepts to the emerging countries of the post-Soviet space [...]. Things move fast in the postcolonial world 9 .

With the collapse of the USSR, a number of scholars suddenly noticed that it had possessed the characteristics of a colonial empire all along ${ }^{10}$. Much like religion, which had been virtually ignored in the Russian context but is now the subject of much academic attention, the study of Empire and Nationality became relevant. During the Cold War, these had been marginalised as everyone pondered such questions as the origins of the Revolution or the rise of the working class. The past twenty years have seen an avalanche of scholarship about, as Andreas Kappeler puts it, "The multinational empire" 11.

In Russian literature, the first candidate for Saidian scrutiny was the prose and poetry inspired by the tsarist campaign to subjugate the Caucasus. Here, during the first half of the 19th century Russians

8. In K. Hokanson, Writing at Russia's Border, p. 3.

9. A. Etkind, Internal Colonization, p. 249.

Io. The imperial nature of the USSR remains controversial. For a discussion of Russia as empire more generally, see, among other, D. Lieven, Empire.

II. A. Kappeler, Russland als Vielvölkerreich. 
fought a bitter and bloody struggle against Muslim highlanders, such as the Circassians and the Chechens on the empire's southern periphery. Some of the most prominent writers of the Golden Age of Russian letters, like Alexander Pushkin, Mikhail Lermontov and Aleksandr Bestuzhev-Marlinskii, saw the action first hand, whether as soldiers or travellers. Strongly influenced by Byronic Romanticism, their work often touched on the Caucasian exotic.

While some American Slavists read these texts through the Saidian lens, others argued that, in fact, Russians often expressed ambivalence about their relationship with the East. In her study of Russian literary depictions of the conquest of the Caucasus Susan Layton points out that, when early 19th-century Russian poets found their muse in the Orient, they were following a broader European trend. If, like Lord Byron, these Russians also travelled to the East, they rarely did so by going abroad. For Pushkin, Lermontov and Bestuzhev-Marlinskii, and the others, the Caucasus was well within their own country's borders. At the same time, their attitudes were not just shaped by the peculiarities of political geography. Although Russia's Romantic poets considered themselves to be European, they were also aware of a special affinity with Asia. According to Susan Layton, "Both culturally and politically Russia has genuine roots in [...] Asia, which made the Orient both self and other" ${ }^{12}$.

A more sophisticated examination of the question began about a decade ago as historians joined the discussion to consider how the East figured into considerations of Russian identity. Beginning in the early 19th century, the famous debate between the Westernisers and the Slavophiles inspired a vast literature about the nation's relationship with Europe. The Westernisers were those who advocated modernisation by continuing to adopt Occidental ways, in other words, to continue Peter the Great's reforms. By contrast, the Slavophiles, championed a distinctly different path. However, even if the Slavophiles saw Russia as very different from the Graeco-Roman tradition, they never considered themselves to be Asian.

If there are dozens of works about Russia and the West ${ }^{13}$, very few had looked at the other side of the coin, namely Asia ${ }^{14}$. Beginning with

I2. S. Layton, Russian Literature and Empire, p. 191.

I3. Most notably N. Ia. Danilevskii, Rossiia i Evropa.

I4. One earlier work in English is M. Hauner, What Is Asia to Us? 
Aldo Ferrari about ten years ago, Lorraine de Meaux, Marlène Laruelle, Jane Sharp, and a handful of others have written about cultural and scholarly representations of the East in Imperial Russia ${ }^{15}$. With some exceptions ${ }^{16}$, most concluded that Said's Manichean approach is not relevant to the Russian example. Russians thought about the Orient in a variety of ways. While some saw it as a source of mystery, danger, and malevolence, many others had more benign and even positive views.

Moreover, some Russians, conscious of their own Asian roots, could identify with the East in opposition to the West. To them, De Maistre's quip, "grattez le Russe et vous trouverez le Tatare", was hardly pejorative. In the 19th century, such ideas were often to be found on the right, among those opposed to such pernicious Western phenomena as civil liberties, secular humanism, parliamentary democracy, and market capitalism. Conservatives, like the diplomat-turned-mystic Konstantin Leont'ev and the newspaper publishers Prince Meshcherskii and Prince Ukhtomskii, championed greater intimacy with the reputedly more autocratic, spiritual and communal East. According to Ukhtomskii, "The West is but dimly reflected in our intellectual life. The depths below us have their being in an atmosphere of deeply Oriental views and beliefs" ${ }^{17}$. These "deeply Oriental views and beliefs" above all championed firm rule:

The east believes no less than we do [...] [in] the most precious of our national traditions - autocracy. Without it, Asia would be incapable of sincere liking for Russia and of painless identification with her ${ }^{18}$.

Similar ideas about Russia's Oriental nature flourished among the poets of the Silver Age, the fin-de-siècle reaction to Realism in Russian letters. Ettore Lo Gatto argued that Silver Age authors likewise looked to the East to set it apart from the West, albeit with less partisan aims:

15. A. Ferrari, La foresta i la steppa; L. de Meaux, La Russie et la tentation de l'Orient; M. Laruelle, Mythe aryen et rêve impérial dans la Russie du XIXe siècle; J. Sharp, Russian Modernism between East and West; S. Gorshenina, S. Abashin, Le Turkestan russe; P. Wageman, I. Kouteinikova, Het Onbekende Rusland; V. Tolz, Russia's Own Orient; D. Schimmelpenninck van der Oye, Russian Orientalism.

I6. Most notably K. Sahni, Crucifying the Orient, and E. M. Thompson, Imperial Knowledge.

17. H. Ookhtomsky, Travels in the East of Nicholas II when Cesarewitch, p. 287.

I8. Ibid., p. 446. 
In Russian poetry, the terms Mongolian, Scythian and Hun are ideological concepts with Slavophile connotations, and they were similarly brandished to proclaim Russia's distinct, so to speak Eurasian, character to the western world ${ }^{19}$.

Aleksandr Blok famously described this notion in his poem of 1918, "The Scythians":

You have your millions. We are hordes, and hordes, and hordes.

Just try it! Take us on!

Yes, we are Scythians! Yes, we're Asians too!

With slanting eyes bespeaking greed! ${ }^{20}$

The idea that Russia should look with pride to its semi-Asian roots persisted through the early Soviet era, among the Eurasianists in exile. Their views that Russia forms a separate "Eurasian" continents combining elements from both East and West, have witnessed a remarkable revival since the USSR's demise some twenty years ago ${ }^{21}$.

Some scholars, like Robert Geraci and Kalpana Sahni, have directly applied the Saidian paradigm about the inextricable link between Orientological scholarship and colonial rule to Imperial Russia's Asian realms ${ }^{22}$. They argue that tsarist Orientology enthusiastically and uncritically served the Romanov autocracy's aggressive territorial designs in the East. But in an interesting twist, Vera Tolz recently suggested that Orientologists actually promoted nationalism among the tsar's Asian minorities during the ancient régime's dying days. Her Russia's Own Orient: The Politics of Identity and Oriental Studies in the Late Imperial and Early Soviet Periods, focuses on the "Rosen School", a group of scholars taught by the Saint Petersburg Arabist Baron Viktor Rosen toward the end of the 19th century ${ }^{23}$. The Rosen School not only dominated vostokovedenie (Orientology) in the late Imperial and early Soviet periods, but also influenced relations with Asian minority nationalities. Working with local elites - in some cases their former research

19. E. Lo Gatto, "Panmongolismo di V. Solovëv, I venienti unni di V. Brjusov e Gli Sciti di A. Blok”, p. 300.

20. A. Blok, Selected Poems, p. 183.

2I. For a good overview, see M. Laruelle, Russian Eurasianism.

22. R. P. Geraci, Window on the East; K. Sahni, Crucifying the Orient.

23. V. Tolz, Russia's Own Orient. 
assistants - they did much to legitimize nascent nationalist aspirations in Eastern Siberia, the Caucasus and Central Asia.

This alliance between Orientologists and Soviet officials was only temporary. It soon foundered as the latter took a more nationalist turn in the 1930's. One of the grimmest reference works in my library is the Bibliographical Dictionary of Oriental Scholars - Victims of Political Repression during the Soviet Era, whose 500 pages contain 750 entries ${ }^{24}$. While it was permissible to accuse Western scholarship of imperialism, criticizing Russian vostokovedy of similar motives was not a good career move in the days of Joseph Stalin.

More intriguing, Tolz draws a direct line from the anti-colonialist critiques of early Soviet Orientology and the ideas of Edward Said. As she reminds us, what sets the discipline in Russia apart is that nation's own semi-Asian identity. Consequently, its practitioners were not always confident about the superiority of European scholarship. And in the wake of the Revolution they readily adapted these doubts to Leninist critiques of Western imperialism. Said didn't read Russian, but he was profoundly influenced by the Paris-based Egyptian socialist Anwar Abdel-Malek. Abdel-Malek's article of 1963, "Orientalism in Crisis", harshly criticized Western Orientology for its racism and service to imperialism, a notion that Said adopted in his own polemic. The first footnote for AbdelMalik's piece is to the entry for Vostokovedenie (Orientology) in the Stalin-era second edition of the Great Soviet Encyclopedia. According to the latter, "Bourgeois Orientology entirely subordinates the study of the East to the colonial politics of the imperialist powers" 25 .

Tolz points out, "Said's work on Orientalism was indebted - via Arab intellectuals of the 1960s who studied in the Soviet Union - to the critique of European Oriental Studies formulated by Ol'denburg and Marr" ${ }^{26}$. Her intellectual genealogy makes sense. She explains that Russians (although, intriguingly, the Rosen School's members were all of non-Russian origin), like Egyptians and Palestinians, are often self-conscious of their peripheral place in the Western academy. Furthermore, whether in Leningrad in the 1920's, the Left Bank in the 1960's, or Morningside Heights in the 1970's, these men were all

24. Ia. V. Vasil'kov, M. Iu. Sorokina, Liudi i sud'byi.

25. Bol'shaia sovetskaia entsiklopediia, 2nd ed., s.v. "Vostokovedenie".

26. V. Tolz, Russia's Own Orient, p. 20. 
strongly influenced by Marxism, with its ideas about superstructures and the oppression of the disadvantaged many by the privileged few.

An even more recent work, Internal Colonization: Russia's Imperial Experience by Alexander Etkind, takes the story full circle ${ }^{27}$. Again written in response to Edward Said, Etkind agrees with his critics that the late Columbia professor ignores Russia. Yet to Etkind, Said is not only relevant to Russian views of Asia but to what he calls "the Nontraditional Orient". By the "non-traditional Orient", Etkind means Russia's own peasant masses. Traditionally dismissed as "temnye liudi", or "dark people", the vast rural masses of Russia were often seen as being just as "Other" as the tsar's Asian subjects. According to Etkind, the process of colonization was both internal and external.

Vera Tolz and Alexander Etkind are both Russian natives, but they are based in the West and are fully conversant with postcolonialist scholarship. What of Russians back in Russia? How has the thought of Edward Said affected them? His ideas would not have seemed out of place in the early Soviet era. In 1922, Novyi Vostok, the journal of the All-Russian Scholarly Association of Orientologists, editorialised that, "the primary goal [of Western Orientology] is to do whatever they to help their respective governments...conquer Asian lands" ${ }^{28}$. Even the erstwhile "prison house of peoples" was not beyond reproach. Writing about Russian Romantic poets like Pushkin and Lermontov, Nikolai Svirin concluded, "so-called Russian 'exotic' literature was basically colonialist" ${ }^{29}$. By the 1930's such ideas were distinctly out of favour in the Stalinist academic establishment.

Today, some younger scholars, especially those with ties to the West, have integrated postcolonialism in their work. Nevertheless, most tend to discount its importance to their own country. Histories of Russian vostokovedenie well into the post-Soviet era have largely been institutional narratives or biographical surveys of prominent Orientologists very much in the Soviet vein - albeit without the requisite genuflections to Karl Marx and Vladimir Lenin in the introduction ${ }^{30}$. Many - but

27. A. Etkind, Internal Colonization.

28. M. Pavlovich, "Zadachi vserossiiskoi nauchnoi assotsiatsii vostokovedeniia”, p. 5.

29. N. G. Svirin, “Russkaia kolonial'naia literatura”, p. 56.

30. See, among others, A. A. Vigasin et al., Istoriia otechestvennogo vostokovedeniia s serediny XIX veka; R. M. Valeev, Kazanskoe vostokovedenie. 
not all - scholars affiliated with the Institute of Oriental Studies and other relevant academic institutions in Russia today still emphatically deny that Edward Said's work has any relevance to their own schools.

A case in point is the relatively late publication of Orientalism into Russian. The book has gone through two revisions in its Englishlanguage original, the second being a 25th anniversary edition with a new preface by the author. By 2005, it had also been translated into 36 other languages. However, it took until 2006 for a Russian version to appear ${ }^{31}$. Meanwhile that translation was made as a critique of Western Orientology, largely echoing earlier, Soviet-era views that British, French and American scholarship of the East was subordinate to their imperial ambitions. By implication, this was not the case for Russia or the Soviet Union.

While academic journals largely ignored it at the time, reviews of the Russian translation in the press were generally positive ${ }^{32}$. As might be expected, leftists were particularly favourable. Writing in Levaia Rossiia (leftist Russia) Il'ia Ioffe remarked, that, while it had nothing to add to Marx and Lenin's teachings about culture, "It will be interesting even for a Marxist to acquaint himself", with Said's critique of the ideology of European colonialism ${ }^{33}$.

More intriguingly, the Russian edition included an afterword by Konstantin Krylov, a leader of the right-oppositionist National Democratic Party ${ }^{34}$. Fellow Russian nationalists enthusiastically applauded the book's criticism of Western Orientalism. As one reviewer with the improbable pseudonym of "Israel Shamir", put it:

Edward Said could not take on the Jewish-American propaganda establishment single-handedly, but he explained its structure. Like the wise raven in Tolkien's Hobbit, he pointed out the dragon's weak spots. He pointed out the tremendous importance of the struggle for the narrative, the spiritual aspect of the ground war. Said understood that the story told about the world by Anglo-American scholars and

3I. E. Said, Orientalizm.

32. See, for example, O. Balla, "No net Vostoka i Zapada net". One notable exception, by a leading scholar of the Caucasus at the Institute of Oriental Studies in Moscow is V. Bobrovnikov, "Pochemu my marginaly?".

33. In V. Bobrovnikov, "Pochemu my marginaly?", p. 337.

34. K. Krylov, “Itogi Saida: zhizn' i kniga...”. 
editorialists precede physical conquest of the globe, that the discourse of meek professors camouflage artillery and aircraft carriers ${ }^{35}$.

More than thirty years after its publication in the West, Orientalism is slowly infiltrating Russian academic discourse. A "Google Scholar" search in Cyrillic for "Edvard Said" and "Orientalizm" yields 65 hits, compared to over 30,000 in English ${ }^{36}$. Russian graduate students in the Humanities, especially at more Western-Oriented institutions, are familiar with his works ${ }^{37}$. Meanwhile, scholars conversant with the relevant North American and West European literature, such as Sergei Abashin and Vladimir Bobrovnikov, have seriously considered Said's work. However, many still deny its applicability to Russia. This is not to say that they dismiss Edward Said's ideas out of hand. But they argue that they apply solely to the West for the very same reasons that Said indirectly appropriated the earlier Soviet discourse about Capitalist Orientalism as a tool of Occidental imperialism. Since Russia is neither Western nor imperialist, it could not possibly apply to its own understanding of Asia. One clear example is that the leading institution for scholarship about the East still proudly calls itself the Oriental Institute of the Russian Academy of Sciences. If in the West, Edward Said has made what was once a neutral term highly pejorative, its Russian equivalent, vostokovedenie, bears no such stigma.

David Schimmelpenninck van Der Oye Brock University

\section{BIBLIOGRAPHY}

Adamovsкy, Ezequiel, Euro-Orientalism: Liberal Ideology and the Image of Russia in France (c. 1740-1880), Bern, Peter Lang, 2006.

35. In V. Bobrovnikov, “Pochemu my marginaly?”, p. 338.

36. <http://scholar.google.ca/scholar> (accessed 01.02.2014).

37. See, e.g., I. N. Inishev, "Programma distsipliny Postcolonial'naia teoriia kul'turologii". 
Ahmad, Aijaz, In Theory: Nations, Classes, Literatures, London, Verso, 2008.

Balla, Ol'ga, "No net Vostoka i Zapada net", Nezavisimaia Gazeta, 10 July 2006: <http://www.ng.ru/ng_exlibris/2006-08-10/6_ amfibia.html> (accessed 01.02.2014).

Barthold, V. V., "Istoriia izucheniia Vostoka v Evrope i Rossii”, in Sochineniia, vol. 9, Moscow, Nauka, 1977, p. 199-482.

Blok, Alexandr, Selected Poems, Oxford, Pergamon Press, 1972.

Bobrovnikov, Vladimir, "Pochemu my marginaly? (Zametki na poliakh russkogo perevoda 'Orientalizma' Edvarda Saida)”, $A b$ Imperio, 2 (2008), p. 325-344.

DanilevskiI, N. Ia., Rossiia i Evropa, Saint Petersburg, Obshchestvennaia pol'za, 1871.

EtKind, Alexander, Internal Colonization: Russia's Imperial Experience, Cambridge, Polity, 2011.

Ferrari, Aldo, La foresta i la steppa: Il mito dell'Eurasia nella cultura russa, Milan, Libri Scheiwiller, 2003.

Geraci, Robert P., Window on the East: National and Imperial Identities in Late Tsarist Russia, Ithaca, Cornell University Press, 2001.

Gorshenina, Svetlana, Abashin, Sergej (éds), Le Turkestan russe: une colonie comme les autres?, Cahiers d'Asie centrale 17/18, Paris, Complexe, 2009.

Hammerbeck, David William, Orientalism, Islam and the Other in Seventeenth and Eighteenth-Century French Theatre, PhD Diss, University of California, Los Angeles, 2002.

Hauner, Milan, What Is Asia to Us? Russia's Asian Heartland Yesterday and Today, Boston, Unwin Hyman, 1990.

Hokanson, Katya, Writing at Russia's Border, Toronto, University of Toronto Press, 2008.

Inishev, I. N., "Programma distsipliny Postcolonial'naia teoriia kul'turologii”, Unpublished course syllabus: Moscow Higher School of Economics, 2012.

IRwIN, Robert, For Lust of Knowing: The Orientalists and their Enemies, London, Allen Lane, 2006.

Kappeler, Andreas, Russland als Vielvölkerreich: Entstehung, Geschichte, Zerfall, München, Beck, 1992.

Khalid, Adeeb, "Russian History and the Debate over Orientalism", Kritika, 1 (2000), p. 691-699. 
Kim, G. F., Shastitko, P. M., Istoriia otechestvennogo vostokovedeniia do serediny XIX veka, Moscow, Nauka, 1990.

KNight, Nathaniel, "Grigor'ev in Orenburg, 1851-1862: Russian Orientalism in the Service of Empire?", Slavic Review, 59 (2000), p. 74-100.

Kogure, Shuzo, Othering around Technology: Techno-Orientalism, Techno-Nationalism, and Identity Formation of Japanese College Students in the United States, PhD Diss, State University of New York at Buffalo, 2006.

Krylov, K., “Itogi Saida: zhizn' i kniga...", in Edward Said, Orientalizm, trans. A. V. Govorunova, Saint Petersburg, Russkii Mir, 2006, p. 598-635.

Laruelle, Marlène, Mythe aryen et rêve impérial dans la Russie du XIX ${ }^{e}$ siècle, Paris, Editions du CNRS, 2005.

-, Russian Eurasianism: An Ideology of Empire, Washington/Baltimore, Woodrow Wilson Center Press/The Johns Hopkins University Press, 2008.

Layton, Susan, Russian Literature and Empire: Conquest of the Caucasus from Pushkin to Tolstoy, Cambridge, Cambridge University Press, 1994.

Lew Is, Bernard, "The Question of Orientalism”, in Islam and the West, New York, Oxford University Press, 1993, p. 99-108.

Lieven, Dominic, Empire: The Russian Empire and its Rivals, London, John Murray, 2000.

Lo Gatto, Ettore, "Panmongolismo di V. Solovëv, I venienti unni di V. Brjusov e Gli Sciti di A. Blok", in For Roman Jakobson, ed. by Morris Halle et al., The Hague, Mouton \& Co., 1956, p. 295-300. MacKenzie, John M., Orientalism: History, Theory and the Arts, Manchester, Manchester University Press, 1995.

Meaux, Lorraine de, La Russie et la tentation de l'Orient, Paris, Fayard, 2010.

Oldenbourg, S. F., «Sovetskoe vostokovedenie», Front nauki i tekhniki, 7-8 (1931), p. 64-66.

Оокнтомsкy, Prince Hesper [Ukhtomskii], Travels in the East of Nicholas II when Cesarewitch, vol. 2, Westminster, Constable, 1900. PARK, Chi Hyun, Orientalism in United States Cyberpunk Cinema from "Blade Runner" to "The Matrix", PhD diss., The University of Texas at Austin, 2004. 
Pavlovich, Mikhail, "Zadachi vserossiiskoi nauchnoi assotsiatsii vostokovedeniia", Novyi Vostok, 1 (1922), p. 3-15.

Sahni, Kalpani, Crucifying the Orient: Russian Orientalism and the Colonization of Caucasus and Central Asia, Bangkok, White Orchid Press, 1997.

SAID, Edward, Orientalism, New York, Vintage Books, 1978.

-, Orientalizm: Zapadnye kontseptsii Vostoka, trans. A. V. Govorunova, Saint Petersburg, Russkii Mir, 2006.

Schimmelpenninck van der Oye, David, Russian Orientalism: Asia in the Russian Mind from Peter the Great to the Emigration, New Haven, Yale University Press, 2010.

Sharp, Jane, Russian Modernism between East and West: Natali'ia Goncharova and the Moscow Avant-Garde, Cambridge, Cambridge University Press, 2006.

Svirin, N. G., “Russkaia kolonial'naia literatura”, Literaturnyi kritik, 9 (1934), p. 51-79.

TaYlor, Susan Beth, "Ruining Oppositions: Orientalism and the Constructions of Empire in British Romanticism", PhD Diss, Brown University, 1993.

Thompson, Ewa M., Imperial Knowledge: Russian Literature and Colonialism, Westport, CT, Greenwood Press, 2000.

Tolz, Vera, Russia's Own Orient: The Politics of Identity and Oriental Studies in the Late Imperial and Early Soviet Periods, Oxford, Oxford University Press, 2011.

Valeev, R. M., Kazanskoe vostokovedenie: istoki i razvitie (XIX-20 gg. $X X v$ v), Kazan, Izdatel'stvo Kazanskogo universiteta, 1998.

VAsil'Kov, Ia. V., Sorokina, M. Iu., Liudi i sud'byi: Biobibliograficheskii slovar' vostokovedov - zhertv politicheskogo terrora $v$ sovetskii period (1917-1991), Saint Petersburg, Peterburgskoe vostokovedenie, 2003.

Vel'tman, Solomon, Vostok v khudozhestvennoi literature, Moscow/ Leningrad, Gosudarstvennoe izdatel'stvo, 1928.

Vigasin, A. A. et al. (eds), Istoriia otechestvennogo vostokovedeniia s serediny XIX veka do 1917 goda, Moscow, Vostochnaia literatura, 1997.

Wageman, Patty, Kouteinikova, Inessa (eds), Het Onbekende Rusland: Oriëntalistische Schilderkunst 1850-1920, Rotterdam, NAI Uitgevers, 2010. 